\title{
Microbial lipid fermentation of Trichosporon cutaneum in high saline water
}

\author{
Luhuan Sun, Shuai Shao and Jie Bao* ${ }^{*}$
}

\begin{abstract}
Fermentative production of microbial lipid requires high fresh water input. The utilization of high saline seawater or industrial wastewater is an important alternative to reduce the freshwater consumption. This study revealed that oleaginous yeast Trichosporon cutaneum was tolerant to a high salinity up to $130 \mathrm{~g} / \mathrm{L}$ of NaCl after long-term adaptive evolution. Lipid fermentation of T. cutaneum in seawater achieved the lipid production of $31.7 \mathrm{~g} / \mathrm{L}$ with approximately $36 \%$ greater than that in freshwater. The saline water containing phenol was also tested for lipid fermentation and $23.6 \mathrm{~g} / \mathrm{L}$ of lipid was produced simultaneously with the complete biodegradation of phenol. An interesting phenomenon was also observed that the yeast cells spontaneously segregated onto the upper surface of the saline water. This study extended the lipid fermentation options with practical application potentials.
\end{abstract}

Keywords: Trichosporon cutaneum, Microbial lipid, Saline water, Phenol degradation, Cell separation

\section{Introduction}

Microbial lipid provides an important alternative of vegetable lipid feedstock for production of aviation fuel and biodiesel (Ju et al. 2016; Li et al. 2008). Oleaginous yeast is the major cell factory for fermentative production of microbial lipid. However, microbial lipid fermentation requires high fresh water input then generates large amount of wastewater, resulting in the heavy burdens of fresh water usage and downstream wastewater treatment (Yen et al. 2016).

One practical solution is to use saline water such as seawater or industrial saline wastewater as alternative of fresh water. Seawater has the typical salinity of $3.5 \%$ and has been used for lipid production by microalgae (Sabeela Beevi and Sukumaran, 2015; Takagi et al. 2006). Oleaginous yeasts Yarrowia lipolytica (Dobrowolski et al. 2019) and Rhodotorula glutinis (Yen et al. 2016) were also tested in seawater, but their cell growth was significantly suppressed. Wastewater from textiles, pharmaceuticals, tannery, petroleum, petrochemical and pickled vegetable

\footnotetext{
${ }^{*}$ Correspondence: jbao@ecust.edu.cn

State Key Laboratory of Bioreactor Engineering, East China University of Science and Technology, 130 Meilong Road, Shanghai 200237, China
}

industries generally has a wide range of salinity from 0.2 to $15 \%$ ( $\mathrm{Ng}$ et al. 2015; von Alvensleben et al. 2013; Yurtsever et al. 2016; Lefebvre and Moletta 2006; Kubo et al. 2001) and contains organic impurities such as phenol (Ren et al. 2018). High saline tolerance and toxin biodegradability of oleaginous yeasts is the pre-condition of saline water used for microbial lipid production.

This study investigated the use of seawater and phenolcontaining saline water for lipid fermentation by a robust oleaginous yeast Trichosporon cutaneum (Hu et al. 2018; Wang et al. 2016). T. cutaneum was found to be tolerant to very high salinity after the long-term adaptive evolution. Adaptive evolution provides a practical method to elevate the robustness of microorganisms under tolerance or inhibitions. For oleaginous yeast strains, adaptive evolution is also a feasible way for improving the lipid accumulation capacity under specific stress such as salinity (Daskalaki et al. 2019). Lipid fermentation of T. cutaneum was conducted under typical salinities of seawater and phenol-containing saline water. An interesting phenomenon was found that the yeast cells floated on upper layer of fermentation liquid in high salt conditions. The result provided a practical and cost-effective method for microbial lipid production using saline water. 


\section{Materials and methods}

\section{Water sources and reagents}

Seawater was taken from East China Sea $\left(30.819^{\circ} \mathrm{N}\right.$, $\left.121.528^{\circ} \mathrm{E}\right)$ at Fengxian Beach, Shanghai, China. The salinity of seawater was $0.98 \%$ and the main metal ions included $3.2 \mathrm{~g} / \mathrm{L}$ of $\mathrm{Na}^{+}, 0.43 \mathrm{~g} / \mathrm{L}$ of $\mathrm{Mg}^{2+}, 0.17 \mathrm{~g} / \mathrm{L}$ of $\mathrm{Ca}^{2+}, 0.11 \mathrm{~g} / \mathrm{L}$ of $\mathrm{K}^{+}$. The seawater was adjusted to different salinities by adding $\mathrm{NaCl}$. The phenol-containing saline water was prepared by adding $35 \mathrm{~g} / \mathrm{L} \mathrm{NaCl}$ and the given amount of phenol into freshwater.

Peptone and yeast extract were purchased from Oxoid Co. (Hampshire, UK). Phenol and other analytical grade chemicals were purchased from Shanghai Titan Scientific Co. (Shanghai, China).

\section{Strains, media and culture conditions}

Trichosporon cutaneum ACCC 20271 was obtained from Agricultural Culture Collection of China (ACCC, http://www.accc.org.cn), Beijing, China. T. cutaneum MP11 was a mutant strain obtained in our lab and stored in China General Microorganisms Collection Center (CGMCC, http://www.cgmcc.net), Beijing, China, with the registration number of 20481.

YPD medium and synthetic medium referred to $\mathrm{Hu}$ et al. (2018), but $60 \mathrm{~g} / \mathrm{L}$ of glucose was added to the synthetic medium instead of inhibitor. The fermentation medium in 3-L bioreactor was supplemented with $150 \mathrm{~g} / \mathrm{L}$ of glucose, and the remaining components were all added twice as much as the synthetic medium.

\section{Lipid fermentation and extraction}

Lipid fermentation was carried out in a 3-L bioreactor (Baoxing Biotech, Shanghai, China) with a working volume of $800 \mathrm{~mL}$. The fermentation was maintained for $120 \mathrm{~h}$ at $30{ }^{\circ} \mathrm{C}$ and $450 \mathrm{rpm}$ with Rushton impeller and pH 5.0 by using $5 \mathrm{M} \mathrm{NaOH}$ and $4 \mathrm{M} \mathrm{HCl}$ solutions.

The microbial lipid was extracted by the methanolchloroform method (Wang et al. 2016).

\section{Analytical methods}

Glucose was measured using the biosensor analyzer SBA-40D (Shandong Academy of Sciences, Jinan, China). The metal ions were measured by ICP-OES (Agilent, California, USA) (Fingerova and Koplik 1999). Cell growth was detected by the method depicted in Jin et al. (2019). Phenol was analyzed using HPLC (Shimadzu, Kyoto, Japan) according to the method described in Kilic (2009).

\section{Results and discussion}

Saline tolerance evolution of $T$. cutaneum under different salinities

Saline tolerance of T. cutaneum ACCC 20271 was examined in the 168-day long-term adaptive evolution (Fig. 1). The salinity was gradually increased by adding sodium chloride into synthetic medium. The results show that T. cutaneum tolerated up to $130 \mathrm{~g} / \mathrm{L}$ of $\mathrm{NaCl}$, an extremely high salinity. The advantage of adaptive evolution is mainly the cell growth in high saline condition. This experiment mainly focused on the evaluation of saline tolerance in the long-term adaptive evolution. In the transfer time 25 , the salt concentration in the medium reached $115 \mathrm{~g} / \mathrm{L}$; in the transfer time 55, the salt concentration reached $130 \mathrm{~g} / \mathrm{L}$. The cell growth maintained constant although the salt concentration increased $13 \%$ in this period. The cell growth decreased with the increasing $\mathrm{NaCl}$ concentration, but still in the relatively normal growth period. The cell morphology maintained relatively unchanged when $\mathrm{NaCl}$ was below $125 \mathrm{~g} / \mathrm{L}$, till the cell corruption at $130 \mathrm{~g} / \mathrm{L}$ of $\mathrm{NaCl} . T$. cutaneum is an environmental microorganism and has strong adaptability to various conditions. This study conducted a preliminary evaluation on lipid fermentation of T. cutaneum under high saline tolerance. The high salinity tolerance of T. cutaneum is speculated to come from the capacity of $T$. cutaneum cells of strong $\mathrm{Na}^{+} / \mathrm{H}^{+}$antitransport activity to pump the intracellular $\mathrm{Na}^{+}$into the extracellular medium under high saline condition. The

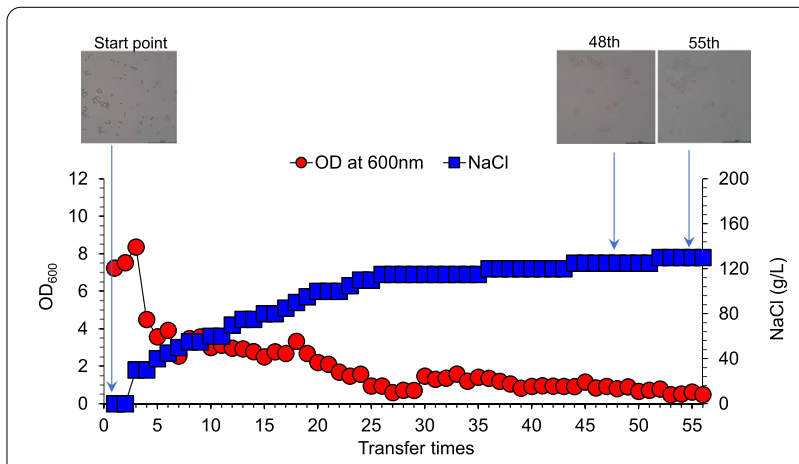

Fig. 1 Adaptive evolution of T. cutaneum ACCC 20271 under varying saline conditions. Synthetic medium supplemented with increasing sodium chloride (from 0 to $130 \mathrm{~g} / \mathrm{L}$ ). The transfer was conducted every $72 \mathrm{~h}$ at $30{ }^{\circ} \mathrm{C}$ into fresh synthetic medium at $10 \%(\mathrm{v} / \mathrm{V})$ inoculation. Cell morphology was observed with an optical electron microscope $(\times 100)$ 
molecular biology mechanism is under investigation and expected to be available in the near future.

Then T. cutaneum ACCC 20271 was used for lipid fermentation in 3-L bioreactor under different salinities. These salinities ranged from 1.0 to $6.0 \%$, corresponding to the salinities of textiles and electro-dialysis wastewater (1.0\%) (Tiwari et al. 2003; Vo et al. 2020; Maeng et al. 2018), aquaculture and seawater (3.5\%) (Zaky et al. 2018; Ren et al. 2017; Song et al. 2018), seawater in arid areas and petrochemical (4.4\%) (Jorfi et al. 2019; Tiwari et al. 2003), tannery and pharmaceutical factories (6.0\%) (Lefebvre et al. 2005; Ng et al. 2015), respectively. Figure 2 shows that the lipid yields at the lower salinity of $1.0 \%$ and $3.5 \%$ were similar to that of freshwater, then decreased when the increasing salinity of $4.4 \%$ and $6.0 \%$. The results indicate that T. cutaneum well tolerated the salinity of $3.5 \%$, but $6.0 \%$ salinity obviously inhibited its lipid production.

\section{Lipid fermentation of T. cutaneum under different salinities} T. cutaneum ACCC20271 has relatively high saline tolerance, but its low lipid production was not suitable for practical lipid fermentation. T. cutaneum MP11 was obtained by long-term adaptive evolution and ultra-centrifugation screening with higher lipid accumulation. Therefore, $T$. cutaneum MP11 was used for lipid fermentation under high salinity condition to evaluate its potentials (Fig. 3). The results show that the higher lipid production was observed at $1.0 \%$ and $3.5 \%$ salinity. With further increase of salinity (up to $4.4 \%$ and $6.0 \%$ ), both the glucose consumption rate

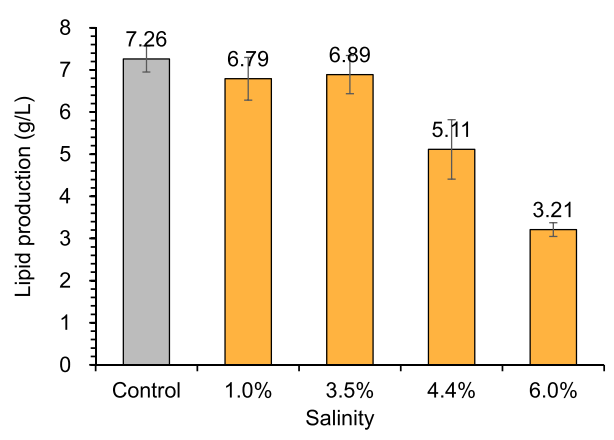

Fig. 2 Lipid production of T. cutaneum ACCC 20271 at different salinities. The lipid production was measured after $120 \mathrm{~h}$ in a 3-L bioreactor with a work volume of $800 \mathrm{~mL}, 10 \%(\mathrm{v} / \mathrm{v})$ inoculum size, $30^{\circ} \mathrm{C}, 450 \mathrm{rpm}, \mathrm{pH} 5.0$ by $5 \mathrm{M} \mathrm{NaOH}$ and $4 \mathrm{M} \mathrm{HCl}$, and the aeration at $1.0 \mathrm{vvm}$. Fresh water was used as the control. All experiments were performed in duplicate and the lipid accumulation decreased. The maximum lipid production $(31.7 \mathrm{~g} / \mathrm{L})$ was obtained at $3.5 \%$ salinity, which was even $36 \%$ greater than that using fresh water $(23.3 \mathrm{~g} / \mathrm{L})$. Only few studies were reported on the microbial lipid fermentation in high saline water. Yen et al. (2016) studied that the growth of $R$. mucilaginosa in seawater using crude glycerol and the lipid production reached $12.2 \mathrm{~g} / \mathrm{L}$. The lipid production $(31.7 \mathrm{~g} / \mathrm{L})$ is the highest that has been reported under high saline condition.

The cell morphology of T. cutaneum MP11 was correlated with the varying salinities (Fig. 4). The yeast cells appeared as long and large rods when the salinity was below 3.5\%, then the cells changed to small round balls at the salinity of $4.4 \%$, and finally shrank and died due to a stronger saline osmotic pressure when the salinity reached $6.0 \%$. The results show that high saline conditions induced strong stress on the cell morphology and then changed the lipid accumulation performance.

An interesting phenomenon was observed that the $T$. cutaneum cells spontaneously floated on the upper layer of the fermentation broth at high saline conditions, while this phenomenon was not observed in the freshwater medium (Fig. 5). The possible reasons might be the higher lipid content in cells in the saline water with higher density. This phenomenon is important for the recovery of microbial lipid.

\section{Lipid fermentation of T. cutaneum under phenol-containing saline water}

Industrial wastewater is the typical saline water containing heavy metals, aromatics and other organic compounds. Phenol is one of the commonly existing organic compounds in various industrial wastewater sources (Jiang et al. 2016; Kamali et al. 2019). The phenol tolerance of $T$. cutaneum MP11 was tested by inoculating into the 3.5\% saline water with different initial phenol concentrations ranging from 700 to $1600 \mathrm{mg} / \mathrm{L}$ (Fig. 6a). The results show that T. cutaneum MP11 was tolerant to $1000 \mathrm{mg} / \mathrm{L}$ of phenol. Metabolic pathway of phenol degradation by T. cutaneum has been not yet well established in the previous studies. However, the pathway of similar phenolic compounds of $p$-hydroxybenzaldehyde, 4-hydroxy-3-methoxybenzaldehyde (vanillin) and syringaldehyde by T. cutaneum has been investigated in our previous studies (Wang et al. 2016; Hu et al. 2018). It is speculated that the phenol degradation by $T$. cutaneum is conducted in a similar way with above phenolic aldehydes. First, phenol is converted to its corresponding alcohol, then further oxidizes into the

(See figure on next page.)

Fig. 3 Cell growth, glucose and lipid production of T. cutaneum MP11 under different salinities. Conditions: a fresh water, b 1.0\% salinity, c 3.5\% salinity, d 4.4\% salinity, e 6.0\% salinity, other fermentation conditions were the same as T. cutaneum. ACCC 20271. All experiments were performed in duplicate 
$\dashv-$ Glucose

(a) Fresh water (Control)

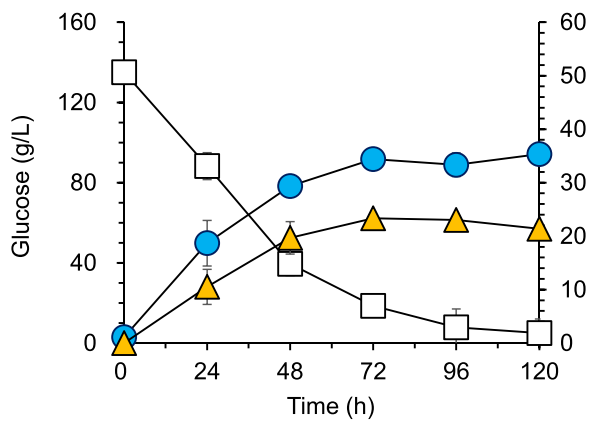

(c) Salinity for seawater (3.5\%)

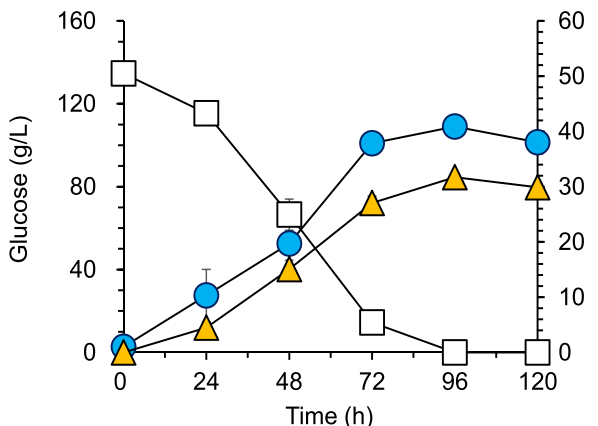

(e) Salinity for pharmaceutical/tannery $(6.0 \%)$

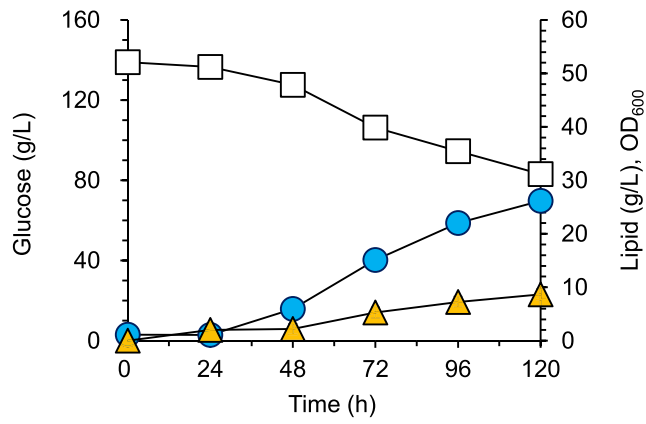

(b) Salinity for textile/electrodialysis effluent (1.0\%)

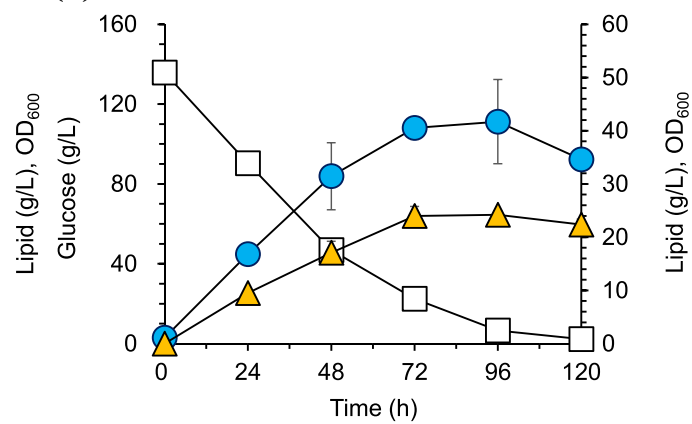

(d) Salinity for seawater/petrochemical (4.4\%)

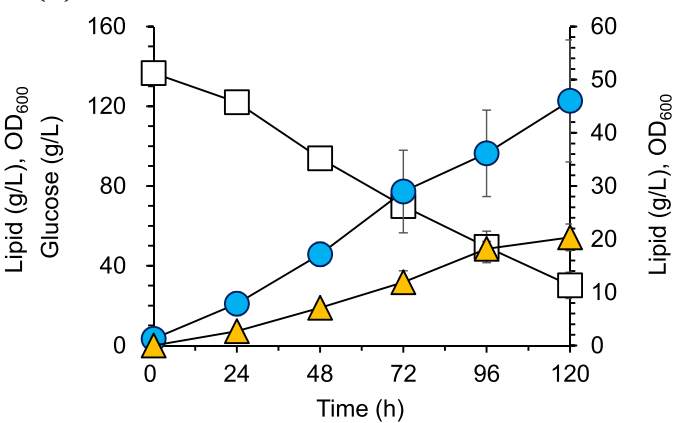

corresponding acid, and finally to acetyl-CoA or succinylCoA as the precursors of TCA cycle or lipid synthesis.

The lipid fermentation of T. cutaneum MP11 was carried out in a 3-L bioreactor under the initial phenol concentration of $1000 \mathrm{mg} / \mathrm{L}$ (Fig. 6b). The initial glucose was adjusted to $60 \mathrm{~g} / \mathrm{L}$, and then added to $150 \mathrm{~g} / \mathrm{L}$ during the fermentation. The cell growth and lipid production $(23.6 \mathrm{~g} / \mathrm{L})$ of $T$. cutaneum MP11 were similar to that in freshwater without phenol. Approximately $76.8 \%$ of phenol was degraded by $T$. cutaneum MP11 at $24 \mathrm{~h}$ and finally approximately consuming all of the phenol added. The result indicates that $T$. cutaneum MP11 not only achieved a high lipid production, but also performed a high phenol degradation under saline wastewater.

\section{Conclusions}

High saline tolerance $(130 \mathrm{~g} / \mathrm{L} \mathrm{NaCl})$ of T. cutaneum was found after the long-term adaptive evolution. A higher lipid production of T. cutaneum was obtained at $3.5 \%$ salinity compared with fresh water and other typical 

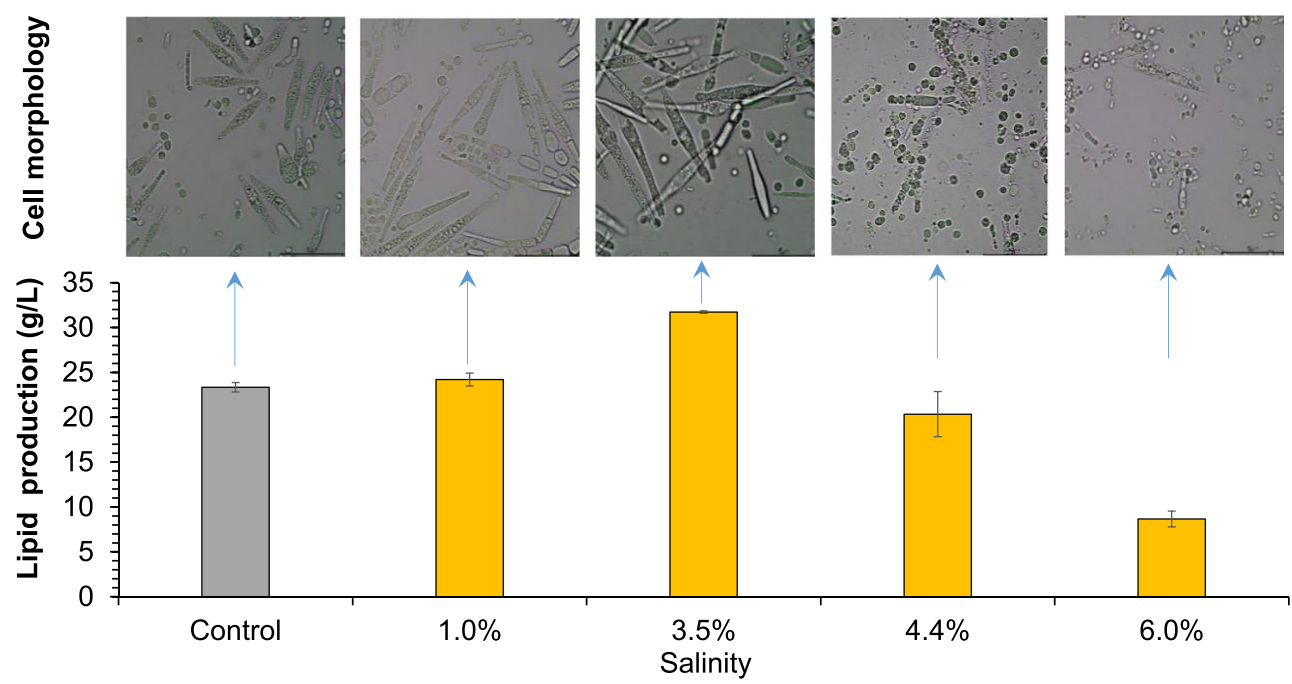

Fig. 4 Lipid production and cell morphology of T. cutaneum MP11 under different salinities. Lipid production was obtained at $96 \mathrm{~h}$ for the control, $1.0 \%$ and $3.5 \%$ salinity, $120 \mathrm{~h}$ for $4.4 \%$ and $6.0 \%$ salinity. Cell morphology was photographed after $96 \mathrm{~h}$ with enlargement of $\times 100$

(a)

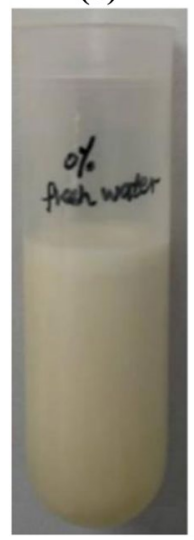

(b)

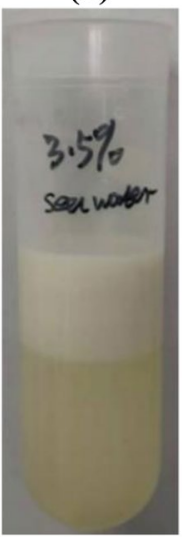

(c)

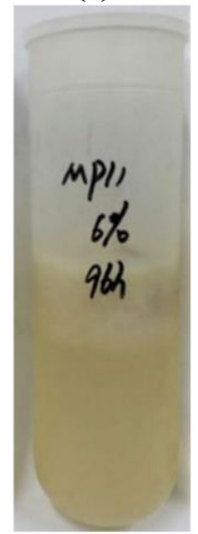

Fig. 5 Broth samples of T. cutaneum MP11 under different salinities. These samples were cultured for $96 \mathrm{~h}$ in a fresh water, b 3.5\% salinity, and c $6.0 \%$ salinity, respectively

salinities. Moreover, T. cutaneum MP11 has the ability of high lipid production $(23.6 \mathrm{~g} / \mathrm{L})$ and phenol degradation $(800 \mathrm{mg} / \mathrm{L})$ under saline wastewater containing phenol. An interesting phenomenon was found that the yeast cells floated on upper layer of fermentation liquid in high salt conditions. The results show that $T$. cutaneum has the potential of lipid production using high saline water. (a) Phenol tolerance at $3.5 \%$ salinity in flasks

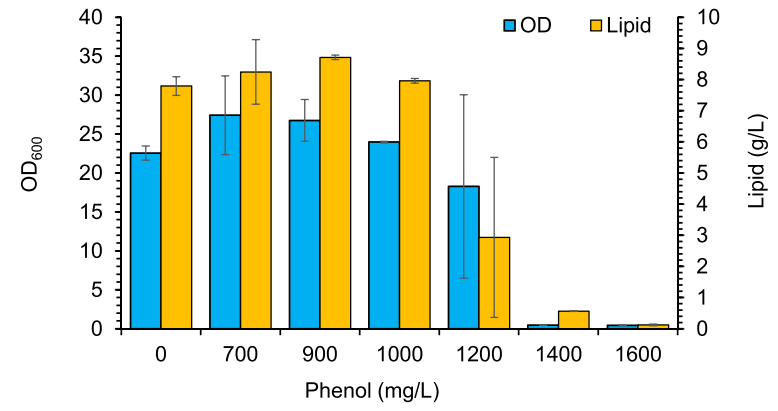

(b) Lipid production under saline/phenol stress in fermenter

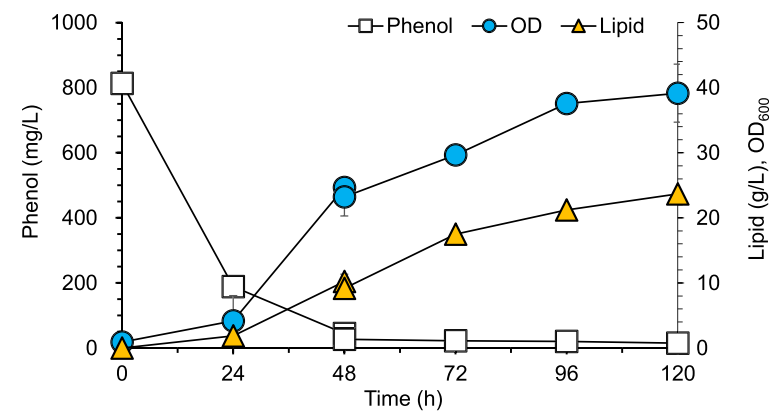

Fig. 6 Phenol tolerance and lipid production of T. cutaneum MP11 in saline water. a Phenol tolerance at $3.5 \%$ salinity in flasks. $35 \mathrm{~g} / \mathrm{L}$ $\mathrm{NaCl}$ and defined phenol were added into the synthetic medium. $T$. cutaneum MP1 1 was cultured at $30^{\circ} \mathrm{C}$ for 120 h. b Lipid production in the medium containing $35 \mathrm{~g} / \mathrm{L}$ of $\mathrm{NaCl}$ and $1000 \mathrm{mg} / \mathrm{L}$ of phenol. The initial concentration of glucose is $60 \mathrm{~g} / \mathrm{L}$, and added to $150 \mathrm{~g} / \mathrm{L}$ at $48 \mathrm{~h}$. All experiments were performed in duplicate 


\section{Acknowledgements \\ Not applicable}

\section{Authors' contributions}

JB conceived and directed the study. LHS conducted the experiment, SS provided material support, LHS and JB analyzed the data and wrote the manuscript. All authors read and approved the final manuscript.

\section{Funding}

This research was supported by the National Natural Science Foundation of China $(21978083,31961133006)$

\section{Availability of data and materials}

All data generated or analyzed during this study are included in this published article.

\section{Declarations}

Ethics approval and consent to participate

Not applicable.

\section{Consent for publication}

Not applicable.

\section{Competing interests}

The authors declare that they have no competing interests.

Received: 13 April 2021 Accepted: 31 July 2021

Published online: 10 August 2021

\section{References}

Daskalaki A, Perdikouli N, Aggeli D, Aggelis G (2019) Laboratory evolution strategies for improving lipid accumulation in Yarrowia lipolytica. Appl Microbiol and Biotechnol 103(20):8585-8596

Dobrowolski A, Drzymala K, Rzechonek DA, Mitula P, Mironczuk AM (2019) Lipid production from waste materials in seawater-based medium by the Yeast Yarrowia lipolytica. Front Microbiol 10:9

Fingerova H, Koplik R (1999) Study of minerals and trace element species in soybean flour. Fresenius J Anal Chem 363(5-6):545-549

Hu MS, Wang J, Gao QQ, Bao J (2018) Converting lignin derived phenolic aldehydes into microbial lipid by Trichosporon cutaneum. J Biotechnol 281:81-86

Jiang Y, Shang Y, Yang K, Wang HY (2016) Phenol degradation by halophilic fungal isolate JS4 and evaluation of its tolerance of heavy metals. Appl Microbiol Biotechnol 100(4):1883-1890

Jin C, Hou WL, Yao RM, Zhou PP, Zhang HS, Bao J (2019) Adaptive evolution of Gluconobacter oxydans accelerates the conversion rate of non-glucose sugars derived from lignocellulose biomass. Bioresour Technol 289:121623

Jorfi S, Ghafari S, Ramavandi B, Soltani RDC, Ahmadi M (2019) Biodegradation of high saline petrochemical wastewater by novel isolated halotolerant bacterial strains using integrated powder activated carbon/activated sludge bioreactor. Environ Prog Sustain Energy 38(4):13088

Ju C, Zhou YP, He ML, Wu QY, Fang YM (2016) Improvement of selectivity from lipid to jet fuel by rational integration of feedstock properties and catalytic strategy. Renew Energy 97:1-7

Kamali M, Gameiro T, Costa ME, Capela I, Aminabhavi TM (2019) Enhanced biodegradation of phenolic wastewaters with acclimatized activated sludge-A kinetic study. Chem Eng J 378:122186

Kilic NK (2009) Enhancement of phenol biodegradation by Ochrobactrum sp isolated from industrial wastewaters. Int Biodeterior Biodegrad 63(6):778-781

Kubo M, Hiroe J, Murakami M, Fukami H, Tachiki T (2001) Treatment of hypersaline-containing wastewater with salt-tolerant microorganisms. J Biosci Bioeng 91(2):222-224

Lefebvre O, Moletta R (2006) Treatment of organic pollution in industrial saline wastewater: a literature review. Water Res 40(20):3671-3682

Lefebvre O, Vasudevan N, Torrijos M, Thanasekaran K, Moletta R (2005) Halophilic biological treatment of tannery soak liquor in a sequencing batch reactor. Water Res 39(8):1471-1480
Li Q, Du W, Liu DH (2008) Perspectives of microbial oils for biodiesel production. Appl Microbiol Biotechnol 80(5):749-756

Maeng SK, Khan W, Park JW, Han I, Yang HS, Song KG, Choi WJ, Kim S, Woo H, Kim HC (2018) Treatment of highly saline RO concentrate using Scenedesmus quadricauda for enhanced removal of refractory organic matter. Desalination 430:128-135

Ng KK, Shi XQ, Ng HY (2015) Evaluation of system performance and microbial communities of a bioaugmented anaerobic membrane bioreactor treating pharmaceutical wastewater. Water Res 81:311-324

Ren LF, Chen R, Zhang XF, Shao JH, He YL (2017) Phenol biodegradation and microbial community dynamics in extractive membrane bioreactor (EMBR) for phenol-laden saline wastewater. Bioresour Technol 244:1121-1128

Ren LF, Adeel M, Li J, Xu C, Xu Z, Zhang XF, Shao JH, He YL (2018) Phenol separation from phenol-laden saline wastewater by membrane aromatic recovery system-like membrane contactor using superhydrophobic/organophilic electrospun PDMS/PMMA membrane. Water Res 135:31-43

Sabeela Beevi U, Sukumaran RK (2015) Cultivation of the fresh water microalga Chlorococcum sp. RAP13 in sea water for producing oil suitable for biodiesel. J Appl Phycol 27(1):141-147

Song WL, Li ZP, Ding Y, Liu F, You H, Qi PS, Wang F, Li YZ, Jin C (2018) Performance of a novel hybrid membrane bioreactor for treating saline wastewater from mariculture: assessment of pollutants removal and membrane filtration performance. Chem Eng J 331:695-703

Takagi M, Karseno YT (2006) Effect of salt concentration on intracellular accumulation of lipids and triacylglyceride in marine microalgae Dunaliella cells. J Biosci Bioeng 101(3):223-226

Tiwari GN, Singh HN, Tripathi R (2003) Present status of solar distillation. Sol Energy 75(5):367-373

Vo HNP, Ngo HH, Guo WS, Chang SW, Nguyen DD, Chen Z, Wang XC, Chen R, Zhang XB (2020) Microalgae for saline wastewater treatment: a critical review. Crit Rev Environ Sci Technol 50(12):1224-1265

von Alvensleben N, Stookey K, Magnusson M, Heimann K (2013) Salinity tolerance of Picochlorum atomus and the use of salinity for contamination control by the freshwater cyanobacterium Pseudanabaena limnetica. PLoS ONE 8(5):12

Wang J, Gao QQ, Zhang HZ, Bao J (2016) Inhibitor degradation and lipid accumulation potentials of oleaginous yeast Trichosporon cutaneum using lignocellulose feedstock. Bioresour Technol 218:892-901

Yen HW, Liao YT, Liu YX (2016) Cultivation of oleaginous Rhodotorula mucilaginosa in airlift bioreactor by using seawater. J Biosci Bioeng 121(2):209-212

Yurtsever A, Calimlioglu B, Gorur M, Cinar O, Sahinkaya E (2016) Effect of $\mathrm{NaCl}$ concentration on the performance of sequential anaerobic and aerobic membrane bioreactors treating textile wastewater. Chem Eng J 287:456-465

Zaky AS, Greetham D, Tucker GA, Du CY (2018) The establishment of a marine focused biorefinery for bioethanol production using seawater and a novel marine yeast strain. Sci Rep 8(1):12127

\section{Publisher's Note}

Springer Nature remains neutral with regard to jurisdictional claims in published maps and institutional affiliations.

\section{Submit your manuscript to a SpringerOpen ${ }^{\circ}$ journal and benefit from:}

- Convenient online submission

Rigorous peer review

- Open access: articles freely available online

- High visibility within the field

Retaining the copyright to your article

Submit your next manuscript at springeropen.com 